\title{
Lovastatin Inhibition of $\alpha$-Farnesene Production in Ripening Apple: Precursor Feeding Studies
}

\author{
Zhiguo Ju and Eric A. Curry \\ U.S. Department of Agriculture, Agricultural Research Service, Tree Fruit Research Laboratory, 1104 \\ North Western Avenue, Wenatchee, WA 98801
}

\begin{abstract}
AdDitional INDEX wORDs. ethylene, hydroxymethylglutaric acid, mevalonic acid, farnesyl pyrophosphate, superficial scald, Malus sylvestris var. domestica
\end{abstract}

\begin{abstract}
Effects of $\alpha$-farnesene biosynthesis precursors on $\boldsymbol{\alpha}$-farnesene and ethylene production were studied using Lovastatin-treated or nontreated 'Delicious' and 'Granny Smith' apples [Malus sylvestris (L.) Mill. var. domestica (Borkh.) Mansf.]. In nontreated fruit, $\alpha$-farnesene was detected only in fruit peel $(\approx 3 \mathrm{~mm})$ and not in the more proximal cortical tissue. $\alpha$-Farnesene was not detectable in preclimacteric fruit peel at harvest. Mevalonic acid lactone (MAL) or farnesyl pyrophosphate (FPP) induced $\alpha$-farnesene production when fed to preclimacteric peel tissue, but hydroxymethylglutaric acid (HMG) did not. Fruit stored at $0{ }^{\circ} \mathrm{C}$ for 30 days (climacteric fruit) produced $\alpha$-farnesene, and addition of HMG, MAL, or FPP further increased $\alpha$-farnesene production. When treated at harvest with Lovastatin at $1.25 \mathrm{mmol} \cdot \mathrm{L}^{-1}$ and stored at $0{ }^{\circ} \mathrm{C}$ for 30 days, fruit produced ethylene but did not produce $\alpha$-farnesene. Whereas MAL and FPP induced $\alpha$-farnesene production in peel sections from these fruit, HMG did not. Induction of $\alpha$-farnesene by precursor feeding was concentration-dependent and had no effect on ethylene production. Cortical tissue sections from climacteric fruit did not produce $\alpha$-farnesene unless HMG, MAL, or FPP were fed during incubation. Including Lovastatin at $0.63 \mathrm{mmol} \cdot \mathrm{L}^{-1}$ in the feeding solution eliminated HMG induced $\alpha$-farnesene production, but did not affect MAL or FPP-induced $\alpha$-farnesene production. Neither precursor feeding nor Lovastatin treatment affected ethylene production in cortical tissues. Chemical name used: $\left[1 \mathrm{~S}-\left[1 \mathrm{a}\left(\mathrm{R}^{\circ}\right), 3 \alpha, 7 \beta, 8 \beta\left(2 \mathrm{~S}^{\circ}, 4 \mathrm{~S}^{\circ}\right), 8 \alpha \beta\right]\right]-1,2,3,7,8,8 \alpha-$-hexahydro-3,7dimethyl-8-[2-(tetrahydro-4-hydroxy-6-oxo-2H-pyran-2-yl)ethyl]-1-naphthalnyl 2-methylbutanoate (Lovastatin).
\end{abstract}

Previous studies (Ju and Curry, 2000a, 2000b) showed that Lovastatin, a competitive inhibitor of hydroxymethylglutaryl Coenzyme-A reductase (HMGR, EC 1.1.1.34) and a potent cholesterol-lowering agent in humans (Alberts et al., 1980), inhibits $\alpha$ farnesene and controls superficial scald without affecting ethylene production in apples (Malus sylvestris var. domestica) and pears (Pyrus communis L.). These results suggest that $\alpha$-farnesene production plays a critical role in superficial scald development and controlling $\alpha$-farnesene biosynthesis through bioengineering may become a feasible mechanism to control scald. However, the biosynthesis and regulation of $\alpha$-farnesene during fruit ripening must be further understood.

$\alpha$-Farnesene belongs to a group of compounds known as isoprenoids. Although the biosynthesis and metabolism of this class of compounds have been well studied in some plants (Bach, 1995; Chappell, 1995), $\alpha$-farnesene biosynthesis and regulation during fruit ripening in apples and pears are poorly understood. The objective of this study was to measure induction of $\alpha$-farnesene by different putative precursors with or without Lovastatin in preclimacteric or climacteric apple tissues, thereby gaining insight regarding regulation of $\alpha$-farnesene biosynthesis during fruit ripening.

\footnotetext{
Received for publication 12 Nov. 1999. Accepted for publication 2 Mar. 2001. This research was supported by the Washington Fruit Tree Research Commission. The authors are grateful to Carol Duplaga, Carol Pavelko, Doris Frederick, Dave Buchanan, and Rodney Roberts from the Tree Fruit Research Laboratory, U.S. Dept. Agr., Agr. Res. Serv., Wenatchee, Wash., for technical support. Mention of a trademark, proprietary product, or vendor does not constitute a guarantee or warranty of the product by the U.S. Dept. Agr. and does not imply its approval to the exclusion of other products or vendors that also may be suitable. The cost of publishing this paper was defrayed in part by the payment of page charges. Under postal regulations, this paper therefore must be hereby marked advertisement solely to indicate this fact.
}

\section{Materials and Methods}

CHEMICALS. Lovastatin was provided by Merck Research Laboratory, Rahway, N.J. The lactone of Lovastatin (8 g) was first dissolved in $120 \mathrm{~g}$ monoglyceride of oleic acid and then mixed with $180 \mathrm{~g}$ Tween 60 and $600 \mathrm{~mL}$ hot water at $90^{\circ} \mathrm{C}$. The microemulsion thus formed contained Lovastatin at $22 \mathrm{mmol} \cdot \mathrm{L}^{-1}$ and was transparent and stable at room temperature (Ju and Curry, 2000b). Appropriate concentrations $\left(0,0.25,1.25\right.$, and $\left.2.5 \mathrm{mmol} \cdot \mathrm{L}^{-1}\right)$ of Lovastatin were obtained by diluting the microemulsion with water. Surfactants were added to the diluted solutions to ensure the same concentration of surfactant in the solutions. Hydroxymethylglutaric acid (HMG), mevalonic acid lactone (MAL), and farnesyl pyrophosphate (FPP) were purchased from Sigma Chemical Company (St. Louis).

Plant materials. 'Delicious' and 'Granny Smith' apples were picked at the time of regular commercial harvest (23 Sept. 1998 for 'Delicious' and 6 Oct. 1998 for 'Granny Smith'). At harvest, one set of fruit (Lot 1) was used directly for precursor feeding experiments. Another set of fruit (Lot 2) was dipped in an emulsion of Lovastatin at $0,0.25,1.25$, or $2.5 \mathrm{mmol} \cdot \mathrm{L}^{-1}$ for $2 \mathrm{~min}$. After drying at $20^{\circ} \mathrm{C}$ overnight, fruit from each treatment were put in separate cardboard boxes (treatments not mixed) and stored at $20{ }^{\circ} \mathrm{C}$ for $30 \mathrm{~d}$. Each treatment contained three replications of 160 fruit in each replication. Both internal ethylene and $\alpha$-farnesene were undetectable at the time of treatment. Thereafter, the internal ethylene concentration and $\alpha$-farnesene production were measured every $6 \mathrm{~d}$ for up to $30 \mathrm{~d}$.

Another set of fruit (Lot 3 ) was harvested from the same orchards on the same days. Half of the fruit were treated with Lovastatin at $1.25 \mathrm{mmol} \cdot \mathrm{L}^{-1}$ for $2 \mathrm{~min}$ and air-dried as described above. The other half were dipped in water for $2 \mathrm{~min}$ and served as the control. Fruit were placed in separate boxes and stored at $0{ }^{\circ} \mathrm{C}$ for $30 \mathrm{~d}$ to initiate the climacteric rise in ethylene biosynthesis. Each treatment contained three replications of 160 fruit in each replication.

$\alpha$-FARNESENE AND INTERNAL ETHYLENE IN WHOLE FRUIT. $\alpha$ - 
Farnesene production in whole fruit of Lot 2 and 3 was measured by gas chromatography-mass spectrometry with a solid phase microextraction (SPME) method. Five fruit from each replication were kept in a 4-L glass jar at $20^{\circ} \mathrm{C}$. The jar was connected to a flowthrough system with a flow rate of $50 \mathrm{~mL} \cdot \mathrm{min}^{-1}$. After equilibrium for $2 \mathrm{~h}$, a 100-mm-thick polydimethylsiloxane (PDMS) probe was introduced into the jar and allowed to adsorb volatiles for $10 \mathrm{~min}$. The probe was inserted immediately into the head inlet assembly of a gas chromatography (HP5890; Hewlett Packard, San Fernando, Calif.). The oven temperature was increased from $35^{\circ} \mathrm{C}$ to $280^{\circ} \mathrm{C}$ at a rate of $60^{\circ} \mathrm{C} \cdot \mathrm{min}^{-1}$ and then held for $3 \mathrm{~min}$. Helium was used as carrier gas and the head pressure was held constant to provide a flow rate of $1 \mathrm{~mL} \cdot \mathrm{min}^{-1}$. The adsorbed volatiles were allowed to desorb for $3 \mathrm{~min}$ in the injector with a constant temperature of $280^{\circ} \mathrm{C} . \alpha$ Farnesene was identified by analysis of fragmentation profiles and confirmatory library matches. It was quantified by the abundance of characteristic ion 93 using mass spectrometry and represented as units per $\mathrm{kg}$ fresh tissue per hour. A reading of 1000 in abundance was defined as one unit. Internal ethylene was measured in 10 individual fruit from each replication using gas chromatography (HP5890, Hewlett Packard) as described previously (Ju and Curry, 2000a).

Precursor feeding. In the precursor feeding experiment, discs were taken from fruit at harvest (Lot 1, preclimacteric fruit), fruit stored at $0{ }^{\circ} \mathrm{C}$ for $30 \mathrm{~d}$ (Lot 3 , climacteric fruit), or fruit treated with Lovastatin at $1.25 \mathrm{mmol} \cdot \mathrm{L}^{-1}$ and stored at $0{ }^{\circ} \mathrm{C}$ for $30 \mathrm{~d}$ (Lot 3 , climacteric fruit with Lovastatin treatment) using a no. 9 brass cork borer with a diameter of $1.2 \mathrm{~cm}$. When cortical tissue was used, cylindrical plugs of tissue were removed from fruit and cut into peel, outer (close to the peel), and inner (mid section of the flesh) cortex segments. All segments were $\approx 3 \mathrm{~mm}$ thick and weighed $\approx 0.3 \mathrm{~g}$. Each treatment included three replications and each replication contained 30 fruit discs. The discs were weighed and put into a $20-\mathrm{mL}$ test tube containing $6 \mathrm{~mL}$ of $1 \%$ of ascorbic acid and different concentrations of precursors for $\alpha$-farnesene synthesis. Precursors used were hydroxymethylglutaric acid (HMG), mevalonic acid lactone (MAL), and farnesyl pyrophosphate (FPP) at 5,25 , and $50 \mathrm{mmol} \cdot \mathrm{L}^{-1}$, respectively. The discs were incubated in the test tube for $10 \mathrm{~min}$ and then transferred to petri dishes and incubated for $4 \mathrm{~h}$ at $20^{\circ} \mathrm{C}$. A piece of tissue paper was put between the lid and the dish to ensure adequate oxygen for aerobic metabolism. After incubation, discs were put into clean test tubes, which were sealed with rubber septae. To accelerate $\alpha$ farnesene diffusion from tissues, $2 \mathrm{~mL}$ of air was removed from the test tube. After an incubation period of $5 \mathrm{~min}$, a $100 \mathrm{~mm}$ polydimethylsiloxane (PDMS) probe was introduced into the jar and allowed to adsorb volatiles for $30 \mathrm{~min}$. The $30 \mathrm{~min}$ adsorption period was used to ensure trace amount of $\alpha$ farnesene from fruit tissue would be detected by this method. $\alpha$-Farnesene was measured as described above and expressed as units per gram fresh weight per min. One unit was defined as 1000 in abundance. Ethylene production rate was measured using gas chromatography by taking a 0.5 -mL air sample from the test tube after $\alpha$-farnesene measurement.

Since $\alpha$-farnesene is highly retained in fruit cuticle, a confirmatory extraction of peel discs for $30 \mathrm{~min}$ in 50 $\mathrm{mL}$ hexane was also used to measure a-farnesene. One microliter hexane extract was injected into the gas chromatography-mass spectrometry using the same column and carrier as the SPME method except oven temperature was increased from 55 to $320^{\circ} \mathrm{C}$ at a rate of $30^{\circ} \mathrm{C} \cdot \mathrm{min}^{-1}$ and held for $7 \mathrm{~min}$.

STATISTICAL ANALYSIS. Data were analyzed by analysis of variance procedures of SAS Statistical Software (SAS Inst. Inc., Cary, N.C.). Means were separated using Duncan's multiple range test at $P \leq 0.05$.

\section{Results}

EFFECT OF LOVASTATIN ON ETHYLNE ACCUMULATION AND $\alpha$ FARNESENE PRODUCTION IN 'DELICIOUS' AND 'GRANNY SMITH' APPLES. During $30 \mathrm{~d}$ at $20{ }^{\circ} \mathrm{C}$, internal ethylene in control fruit increased during early storage, reaching a maximum concentration by day 18 in 'Granny Smith' and by day 24 in 'Delicious', and decreased by the end of the storage period (Figs. 1A and 2A). Lovastatin treatment at any concentration did not affect internal ethylene concentration in either cultivar. Although $\alpha$-farnesene in control fruit was not detectable at harvest, it increased early and then remained constant (Figs. 1B and 2B). Lovastatin reduced $\alpha$-farnesene production in a concentration dependent manner. In 'Delicious', none of the concentrations of Lovastatin completely inhibited $\alpha$-farnesene production by the end of storage. In 'Granny Smith', however, Lovastatin at $2.5 \mathrm{mmol} \cdot \mathrm{L}^{-1}$ controlled $\alpha$-farnesene production completely during the storage period.

EFFECTS OF PRECURSOR FEEDING ON $\alpha$-FARNESENE PRODUCTION IN PEEL DISCS FROM PRECLIMACTERIC AND CLIMACTERIC FRUIT. Internal ethylene (IE) in fruit at harvest was undetectable in both 'Delicious' and 'Granny Smith' apples (preclimacteric fruit, $\mathrm{IE}<1 \mathrm{~mL} \cdot \mathrm{L}^{-1}$, data

Fig. 1. Effects of Lovastatin treatment on (A) internal ethylene accumulation and (B) $\alpha$-farnesene production in 'Granny Smith' apples. Vertical bars $=\operatorname{SE}(n=3)$.

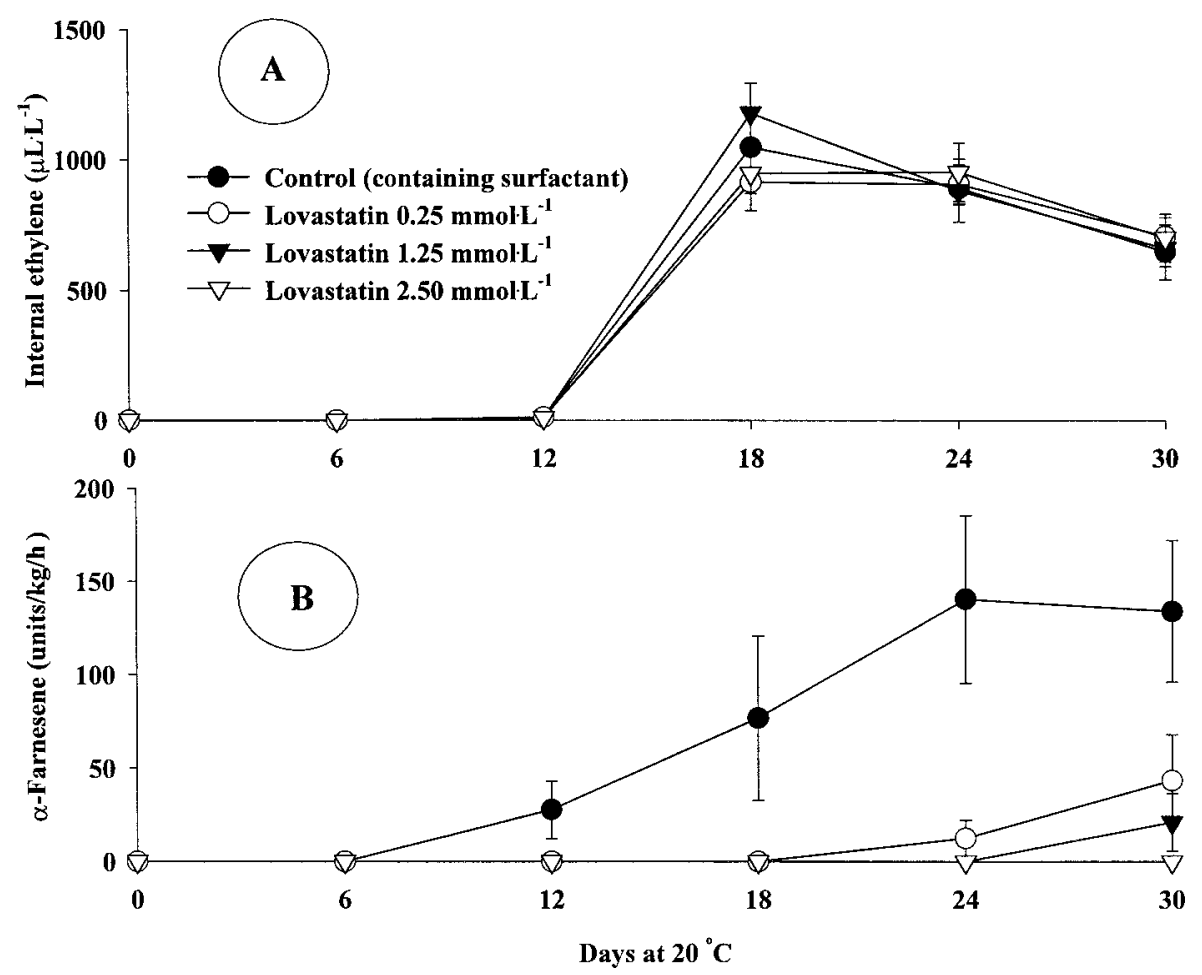



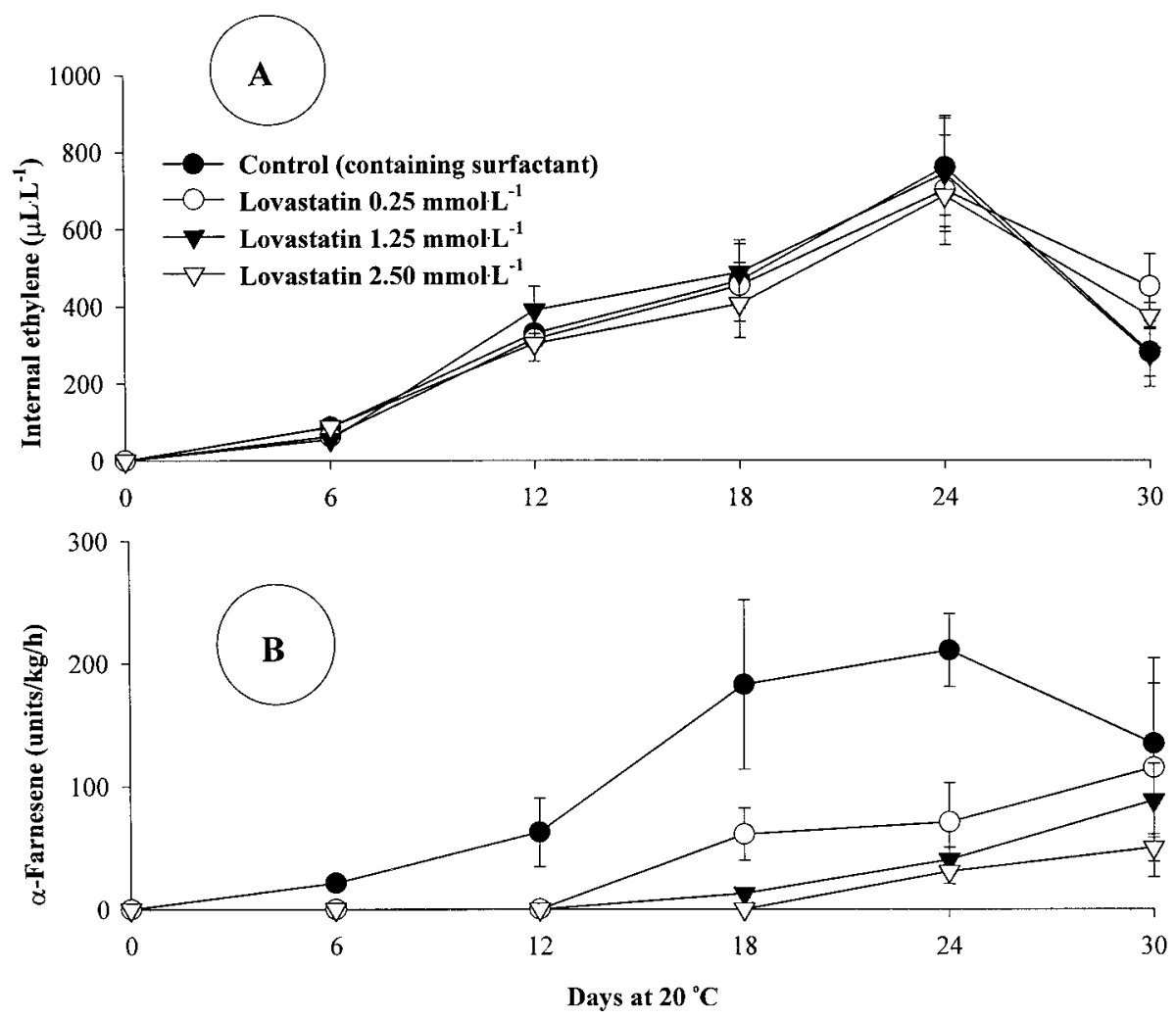

Fig. 2. Effects of Lovastatin treatment on (A) internal ethylene accumulation and (B) $\alpha$-farnesene production in 'Delicious' apples. Vertical bars $=\operatorname{SE}(n=3)$.

not presented). $\alpha$-Farnesene in fruit peel discs was not detectable using either headspace analysis (Table 1), or analysis of hexane extraction (data not presented). After $30 \mathrm{~d}$ storage at $0^{\circ} \mathrm{C}$, fruit began producing ethylene (climacteric fruit, IE $>1 \mathrm{~mL} \cdot \mathrm{L}^{-1}$, data not presented) and $\alpha$-farnesene (Table 1). MAL and FPP induced $\alpha$ farnesene production in peel discs from preclimacteric fruit, but HMG did not. In contrast, all three precursors increased $\alpha$-farnesene production in peel discs from climacteric fruit of both cultivars,. At the same concentration, promotion of $\alpha$-farnesene production by precursors followed the order: FPP $>$ MAL > HMG. None of the precursor treatments affected ethylene production (data not presented).

Adding FPP to climacteric fruit peel induced four to five times more $\alpha$-farnesene production than adding FPP to preclimacteric fruit peel. The increase of $\alpha$-farnesene production by MAL was 6-fold higher in climacteric peel than preclimacteric peel of 'Delicious' and 15-fold higher in climacteric peel than in preclimacteric peel of 'Granny Smith'.

EFFECTS OF PRECURSOR FEEDING ON $\alpha$ FARNESENE PRODUCTION IN PEEL DISCS FROM LOVASTATIN-TREATED AND NONTREATED FRUIT. Lovastatin $\left(1.25 \mathrm{mmol} \cdot \mathrm{L}^{-1}\right)$ treatment at harvest did not affect internal ethylene concentration after $30 \mathrm{~d}$ at $0{ }^{\circ} \mathrm{C}$ (data not presented) but inhibited $\alpha$-farnesene production in both cultivars (Table 1). While all three precursors increased $\alpha$-farnesene production in peel discs from nontreated fruit, only MAL and FPP induced $\alpha$-farnesene in peel discs from Lovastatin-treated fruit, whereas HMG did not (Table 1, Fig. 3). The increase in $\alpha$ farnesene production induced by MAL (Fig. 3), HMG, or FPP (data not presented) was concentration dependent. FPP induced more $\alpha$-farnesene than MAL at the same concentration (Table 1). Neither precursor feeding nor Lovastatin treatment affected ethylene production (data not presented).

In 'Delicious', adding MAL to Lovastatin-treated climacteric fruit peel induced less $\alpha$-farnesene production than in nontreated climacteric fruit peel tissue, but similar levels to that from preclimacteric fruit peel. Adding FPP, however, induced more $\alpha$ farnesene in Lovastatin-treated climacteric peel than in preclimacteric peel and less $\alpha$-farnesene than in Lovastatin-nontreated climacteric peel. In 'Granny Smith', adding MAL or FPP to Lovastatin-treated peel tissue resulted in more $\alpha$-farnesene than in nontreated preclimacteric peel and less $\alpha$-farnesene than in Lovastatin-

Table 1. Effects of Lovastatin and precursor feeding on $\alpha$-farnesene synthesis in fruit peel of 'Delicious' and 'Granny Smith' apples.

\begin{tabular}{|c|c|c|c|}
\hline \multirow[b]{2}{*}{ Treatment $^{2}$} & \multicolumn{3}{|c|}{$\alpha$-Farnesene (units/g/min) } \\
\hline & $\begin{array}{c}\text { Day 0 } \\
\text { (Preclimacteric fruit) }^{\mathrm{y}}\end{array}$ & $\begin{array}{c}\text { Day } 30 \\
(\text { Climacteric fruit })^{\mathrm{x}}\end{array}$ & $\begin{array}{c}\text { Day } 30 \\
(\text { Lovastatin }+ \text { Climacteric fruit })^{\mathrm{w}}\end{array}$ \\
\hline & & 'Delicious' & \\
\hline Control & $0 c^{v}$ & $37 \mathrm{~d}$ & $0 \mathrm{c}$ \\
\hline $\mathrm{HMG}\left(50 \mathrm{mmol} \cdot \mathrm{L}^{-1}\right)$ & $0 \mathrm{c}$ & $59 \mathrm{c}$ & $0 \mathrm{c}$ \\
\hline MAL $\left(50 \mathrm{mmol} \cdot \mathrm{L}^{-1}\right)$ & $24 \mathrm{~b}$ & $142 \mathrm{~b}$ & $16 \mathrm{~b}$ \\
\hline \multirow[t]{2}{*}{$\mathrm{FPP}\left(50 \mathrm{mmol} \cdot \mathrm{L}^{-1}\right)$} & $68 \mathrm{a}$ & $219 \mathrm{a}$ & $175 \mathrm{a}$ \\
\hline & & 'Granny Smith' & \\
\hline Control & $0 \mathrm{c}$ & $21 \mathrm{~d}$ & $0 \mathrm{c}$ \\
\hline $\mathrm{HMG}\left(50 \mathrm{mmol} \cdot \mathrm{L}^{-1}\right)$ & $0 \mathrm{c}$ & $42 \mathrm{c}$ & $0 \mathrm{c}$ \\
\hline MAL $\left(50 \mathrm{mmol} \cdot \mathrm{L}^{-1}\right)$ & $7 \mathrm{~b}$ & $105 \mathrm{~b}$ & $85 \mathrm{~b}$ \\
\hline $\operatorname{FPP}\left(50 \mathrm{mmol} \cdot \mathrm{L}^{-1}\right)$ & $32 \mathrm{a}$ & $154 \mathrm{a}$ & $121 \mathrm{a}$ \\
\hline
\end{tabular}

${ }^{\mathrm{z}} \mathrm{HMG}=$ hydroxymethylglutaric acid, $\mathrm{MAL}=$ mevalonic acid lactone, and FPP $=$ farnesyl pyrophosphate.

yPreclimacteric fruit were fruit at harvest when internal ethylene was under detectable levels.

${ }^{\mathrm{x}}$ Climacteric fruit were fruit with internal ethylene above $1 \mathrm{~mL} \cdot \mathrm{L}^{-1}$ after $30 \mathrm{~d}$ storage at $0{ }^{\circ} \mathrm{C}$.

${ }^{\mathrm{w}}$ Lovastatin + climacteric fruit represent fruit treated at harvest with Lovastatin at $1.25 \mathrm{mmol} \cdot \mathrm{L}^{-1}$ and stored at $0{ }^{\circ} \mathrm{C}$ for $30 \mathrm{~d}$ when internal ethylene was above $1 \mathrm{~mL} \cdot \mathrm{L}^{-1}$.

'Mean separation within columns for a cultivar by Duncan's multiple range test at $P \leq 0.05$. 


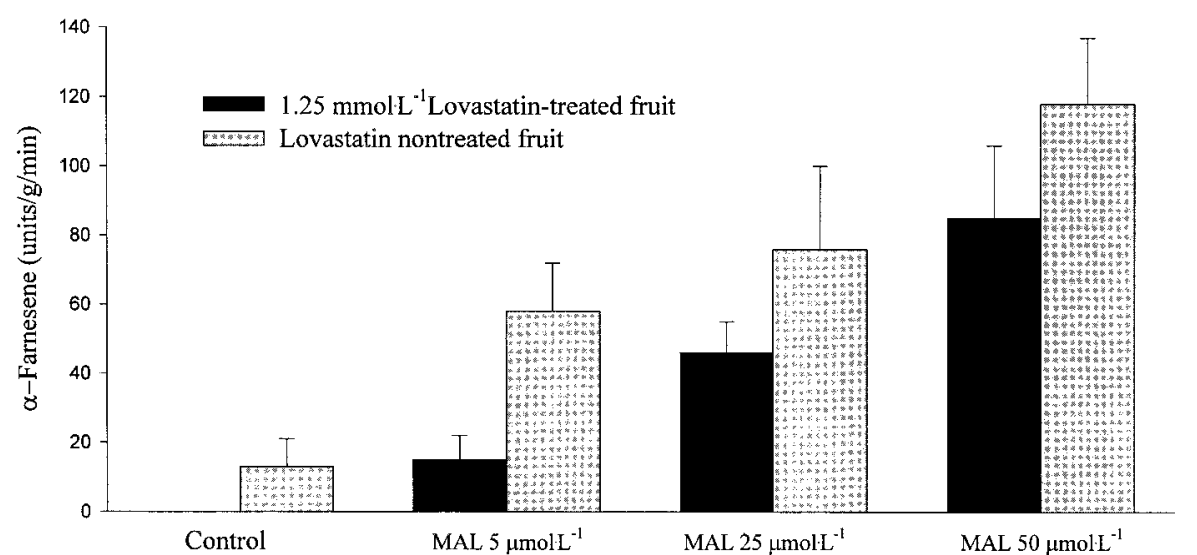

Treatment

Fig. 3. Effects of precursor concentration on $\alpha$-farnesene production in Lovastatintreated and nontreated fruit peel of 'Granny Smith' apples. Peels were from fruit treated with Lovastatin at $1.25 \mathrm{mmol} \cdot \mathrm{L}^{-1}$ and stored at $0{ }^{\circ} \mathrm{C}$ for $30 \mathrm{~d}$. $\mathrm{MAL}=$ Mevalonic acid lactone. Vertical bars $=\operatorname{SE}(n=6)$.

nontreated climacteric peel tissue. Compared with the control (no Lovastatin or precursor), $\alpha$-farnesene production in Lovastatintreated 'Delicious' peel was reduced by MAL feeding and increased $\approx 4$-fold by FPP feeding. In 'Granny Smith' $\alpha$-farnesene production was increased $\approx 4$ - and 6-fold by feeding with MAL and FPP, respectively.

EFFECTS OF PRECURSOR FEEDING ON $\alpha$-FARNESENE PRODUCTION IN CORTICAL TISSUES FROM CLIMACTERIC FRUIT. In both 'Delicious' and 'Granny Smith' fruit, $\alpha$-farnesene was detected only in peel of climacteric fruit (Fig. 4). Nontreated cortical tissues did not produce $\alpha$-farnesene. In contrast, HMG, MAL, or FPP induced $\alpha$-farnesene production in both peel and cortical tissues (Table 2). Precursorinduced $\alpha$-farnesene production was similar in outer and inner cortex. FPP feeding induced more $\alpha$-farnesene than MAL, which induced more than $\mathrm{HMG}$. When Lovastatin at $0.63 \mathrm{mmol} \cdot \mathrm{L}^{-1}$ was added to the feeding solution, however, only MAL or FPP induced $\alpha$-farnesene synthesis, whereas HMG did not. Lovastatin had no affect on the amount of $\alpha$-farnesene induced by MAL and FPP. Ethylene production was higher in fruit peel $\left(27 \mathrm{~mL} \cdot \mathrm{kg}^{-1} \cdot \mathrm{h}^{-1}\right)$ than in cortical tissue $\left(8 \mathrm{~mL} \cdot \mathrm{kg}^{-1} \cdot \mathrm{h}^{-1}\right)$, but was unaffected by any of the treatments (data not presented).

\section{Discussion}

In plants, two pathways lead to formation of isopentenyl pyrophosphate (IPP), the common precursor for biosynthesis of isoprenoid derivatives such as chlorophyll, carotenoids, sterols, terpenoids, and growth hormones (Bach, 1995; McGarvey and Croteau, 1995). The mevalonate pathway involves acetyl-CoA and mevalonic acid in the cytosol (Bach, 1995; Chappell, 1995), whereas the Rohmer Pathway is through pyruvate and glyceraldehyde-3-phosphate in chloroplasts (Eisenreich et al., 1996; Lichtenthaler et al., 1997; Schwenderetal., 1996). While the mevalonate pathway requires HMGR, the Rohmer pathway does not. The high efficacy of Lovastatin Smith' apples. treatment on inhibition of $\alpha$-farnesene production in both 'Delicious' and 'Granny Smith' apples, together with our previous results (Ju and Curry, 2000a, 2000b), suggest that the mevalonate pathway is the major pathway for $\alpha$-farnesene biosynthesis in apple fruit during ripening.

All putative precursors (HMG, MAL, and FPP) tested enhanced production of $\alpha$ farnesene when fed to peel or cortical tissue of climacteric fruit (Tables 1 and 2), suggesting these compounds may be intermediates for $\alpha$ farnesene biosynthesis in apples. The immediate precursor, FPP, was more effective for inducing $\alpha$-farnesene than MAL, which was more effective than HMG. Rupasinghe et al. (1998) induced more farnesol than $\alpha$-farnesene with radio labeled FPP, but we were unable to detect farnesol in our feeding experiments (data not presented). Using standard farnesol, we found its retention time was $\approx 9 \mathrm{~min}$, compared with $7.7 \mathrm{~min}$. for $\alpha$-farnesene, confirming adequate separation and detection of the two compounds by our methods.

It has been suggested $\alpha$-farnesene synthase, an enzyme that catalyzes the last step in the formation of $\alpha$-farnesene, may play an important role in regulating $\alpha$-farnesene production in apples (Rupasinghe et al., 2000). On the other hand, our data as well as other published work indicate inconsistencies in this hypothesis. For example, $\alpha$-farnesene and $\alpha$-farnesene synthase activity showed a correlative increase during 16 weeks of storage at $0{ }^{\circ} \mathrm{C}$, yet enzyme activity was also detected in preclimacteric fruit at harvest although no $\alpha$-farnesene was produced (Rupasinghe et al., 2000). Furthermore, if $\alpha$-farnesene synthase is the key point for regulating $\alpha$ farnesene biosynthesis, it must be determined why 1) preclimacteric fruit do not produce $\alpha$-farnesene and 2 ) adding MAL or FPP to peel

Fig. 4. Spectrum of volatiles produced in (A1) fruit peel, (A2) outer cortex, and (A3) inner cortex tissues of the same fruit of climacteric 'Delicious' or 'Granny

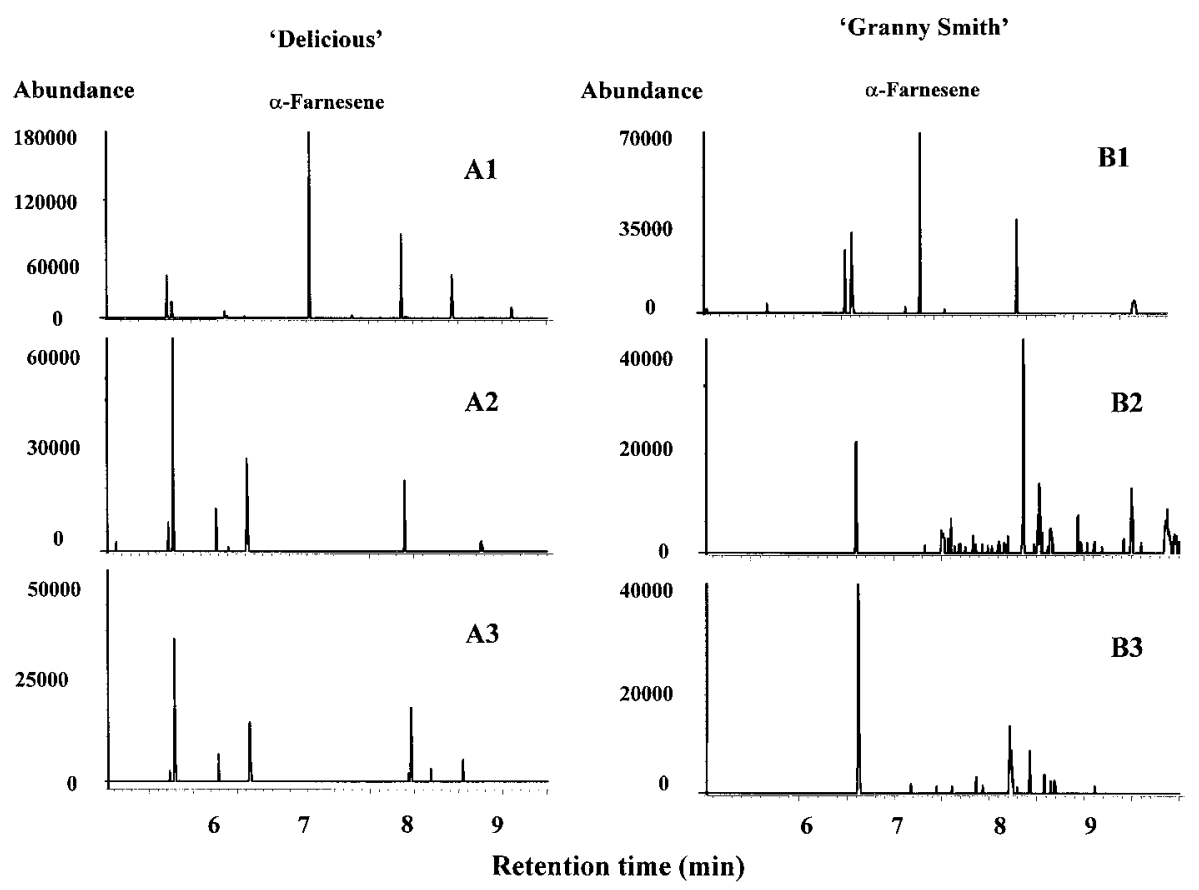


Table 2. Effects of Lovastatin and precursor feeding on $\alpha$-farnesene synthesis in cortex tissues of 'Delicious' and 'Granny Smith' apples.

\begin{tabular}{|c|c|c|c|c|}
\hline \multirow[b]{2}{*}{ Tissue } & \multirow[b]{2}{*}{$\begin{array}{c}\text { Lovastatin } \\
\left(0.63 \mathrm{mmol} \mathrm{L}^{-1}\right)\end{array}$} & \multicolumn{3}{|c|}{$\alpha$-Farnesene (units/g/min) } \\
\hline & & $\begin{array}{c}\mathrm{HMG}^{\mathrm{z}} \\
(50 \mathrm{mM})\end{array}$ & $\begin{array}{c}\text { MAL } \\
(50 \mathrm{mM})\end{array}$ & $\begin{array}{c}\text { FPP } \\
(50 \mathrm{mM})\end{array}$ \\
\hline \multirow{3}{*}{$\begin{array}{l}\text { Outer cortex } \\
+\end{array}$} & & \multicolumn{3}{|c|}{ 'Delicious' } \\
\hline & - & $2.9 \mathrm{a}^{\mathrm{y}}$ & $7.0 \mathrm{~b}$ & $32.0 \mathrm{c}$ \\
\hline & & $0.0 \mathrm{a}$ & $6.4 \mathrm{~b}$ & $34.4 \mathrm{c}$ \\
\hline ANOVA & $*$ & NS & NS & \\
\hline Inner cortex & - & $2.2 \mathrm{a}$ & $5.6 \mathrm{~b}$ & $33.8 \mathrm{c}$ \\
\hline+ & & $0.0 \mathrm{a}$ & $7.1 \mathrm{~b}$ & $27.0 \mathrm{c}$ \\
\hline \multirow[t]{2}{*}{ ANOVA } & $*$ & NS & & \\
\hline & & \multicolumn{3}{|c|}{ 'Granny Smith' } \\
\hline Outer cortex & - & $5.1 \mathrm{a}$ & $9.9 \mathrm{~b}$ & $42.9 \mathrm{c}$ \\
\hline+ & & $0.0 \mathrm{a}$ & $8.3 \mathrm{~b}$ & $38.7 \mathrm{c}$ \\
\hline ANOVA & $*$ & NS & NS & \\
\hline \multirow[t]{2}{*}{ Inner cortex } & - & $4.28 \mathrm{a}$ & $7.82 \mathrm{~b}$ & $37.84 \mathrm{c}$ \\
\hline & + & $0 \mathrm{a}$ & $9.10 \mathrm{~b}$ & $38.94 \mathrm{c}$ \\
\hline ANOVA & $*$ & NS & NS & \\
\hline
\end{tabular}

${ }^{\mathrm{z}} \mathrm{HMG}=$ hydroxymethylglutaric acid, MAL = mevalonic acid lactone, and FPP = farnesyl pyrophosphate.

y Mean separation within rows by Duncan's multiple range test at $P \leq 0.05$.

ss, ${ }^{*}$ Nonsignificant or significant at $P \leq 0.05$, respectively.

discs from preclimacteric fruit induces $\alpha$-farnesene production (Table 1).

Our results indicate that rather than at the final step, the regulating point of $\alpha$-farnesene biosynthesis during fruit ripening may be located at the site of conversion of HMG CoA to mevalonic acid. This is supported in that HMG induced $\alpha$-farnesene production in climacteric fruit tissue but not in preclimacteric or Lovastatintreated climacteric fruit tissue, while MAL or FPP induced $\alpha$ farnesene production in both preclimacteric and climacteric fruit tissue. Therefore, the difference is that climacteric fruit can convert HMG to $\alpha$-farnesene while preclimacteric fruit can not. There are at least two steps from HMG to MAL, esterification of HMG to HMG CoA and reduction of HMG CoA to MAL (Bach, 1995; Chappell, 1995). While esterification of HMG to HMG CoA needs a thioesterase, formation of MAL from HMG CoA is controlled by HMG CoA reductase (HMGR) (Bach, 1995; Chappell, 1995). Whether HMGR and/or the thioesterase are key regulatory enzymes is not clear but HMGR seems more likely. In climacteric fruit peels, $\alpha$-farnesene was normally produced and therefore, we presume both HMGR and the thioesterase are present in these tissues. In fruit treated with Lovastatin at harvest and kept at the same storage condition, however, $\alpha$-farnesene production was inhibited. Since both MAL and FPP induced $\alpha$-farnesene production in Lovastatintreated tissue and HMG did not, it is possible that Lovastatin inhibits either the thioesterase, or HMGR, or both. Because there is no evidence that Lovastatin inhibits thioesterase activity, HMGR is likely the key regulatory enzyme in the biosynthesis of $\alpha$-farnesene. More evidence is needed to support this hypothesis.

Compared with peel tissue from preclimacteric fruit, that from climacteric fruit produced four to five times more $\alpha$-farnesene when FPP was added and up to 10 times more $\alpha$-farnesene when MAL was added, indicating the conversion rate in preclimacteric fruit was lower than in climacteric fruit. These data are consistent with results of Rupasinghe et al. (2000) that $\alpha$-farnesene synthase activity increased during fruit ripening. Therefore, while the step or steps before formation of mevalonic acid may act as the on/off switch for the biosynthesis of $\alpha$-farnesene during fruit ripening, enzyme activity in the later steps may affect the rate of $\alpha$-farnesene production.
By analyzing different tissues in apple fruit, we found that fruit peel produced much higher levels of ethylene compared with cortex tissue $\left(\approx 27 \mathrm{~mL} \cdot \mathrm{kg}^{-1} \cdot \mathrm{h}^{-1}\right.$ in fruit peel vs. $8 \mathrm{~mL} \cdot \mathrm{kg}^{-1} \cdot \mathrm{h}^{-1}$ in cortex tissues). We also confirmed the finding that normally, $\alpha$-farnesene is produced only in fruit peel (Huelin and Murray, 1966; Murray, et al., 1964) and not in cells from the cortex (Rupasinghe, et al., 1998). Nevertheless, cortical tissue from climacteric fruit could be induced to produce $\alpha$-farnesene with HMG, MAL, or FPP. Whether the required enzymes are constitutive or produced de novo requires further study.

\section{Literature Cited}

Alberts, A.W., J. Chen, G. Kuron, V. Hunt, J. Huff, C. Hoffman, J. Rothrock, M. Lopez, H. Joshua, E. Harris, A. Patchett, R. Monagan, S. Currie, E. Stapley, G. Albers-Schonberg, O. Hensens, J. Hirshfield, K. Hoogsteen, J. Liesch, and J. Springer. 1980. Mevinolin: A highly potent competitive inhibitor of hydroxymethylglutaryl-coenzyme A reductase and a cholesterol-lowering agent. Proc. Natl. Acad. Sci. USA 77:3957-3961.

Bach, T.J. 1995. Some new aspects of isoprenoid biosynthesis in plants: A review. Lipids 30:191-202.

Chappell, J. 1995. Biochemistry and molecular biology of the isoprenoid biosynthesis pathway in plants. Annu. Rev. Plant Physiol. Plant Mol. Biol. 46:521-547.

Eisenreich, W., B. Menhard, P.J. Hylands, M.H. Zenk, and A. Bacher. 1996. Studies on the biosynthesis of taxol: The taxane carbon is not of mevalonoid origin. Proc. Natl. Acad. Sci. USA 93:6431-6436.

Huelin, F.E. and K.E. Murray. 1966. $\alpha$-Farnesene in the natural coating of apples. Nature (London ) 210:1260-1261.

Ju,Z. and A. Curry. 2000a. Lovastatin inhibits $\alpha$-farnesene synthesis without affecting ethylene production during fruit ripening in 'Golden Supreme' apples. J. Amer. Soc. Hort. Sci. 125:105-110.

Ju, Z. and A. Curry. 2000b. Lovastatin inhibits $\alpha$-farnesene biosynthesis and scald development in 'Delicious' and 'Granny Smith' apples and 'd'Anjou' pears. J. Amer. Soc. Hort. Sci. 125:626-629.

Lichtenthaler, H.K., J. Schwerder, and M. Rohmer. 1997. Two independent biochemical pathways for isopentyl diphosphate and isoprenoid biosynthesis in higher plants. Physiol. Plant. 101:643-652.

McGarvey, D.J. and R. Croteau. 1995. Terpenoid metabolism. Plant Cell 7:1015-1026.

Murray, K.E., F.E. Huelin, and J.B. Davenport. 1964. Occurrence of $\alpha$-farnesene in the natural coating of apples. Nature (London) 204:80.

Rupasinghe, H.P.V., G. Paliyath, and D.P. Murr. 1998. Biosynthesis of $\alpha$-farnesene and its relation to superficial scald development in 'Delicious' apples. J. Amer. Soc. Hort. Sci. 123:882-886.

Rupasinghe, H.P.V., G. Paliyath, and D.P. Murr. 2000. Sesquiterpene $\alpha$-farnesene synthase: Partial purification, characterization, and activity in relation to superficial scald development in apples. J. Amer. Soc. Hort. Sci. 125: 111-119.

Schwender, J., M. Seemann, H.K. Lichtenthaler, and M. Rohmers. 1996. Biosynthesis of isoprenoid (carotenoids, sterols, prenyl side chains of chlorophylls and plastoquinone) via a novel pyruvate/glyceraldehyde 3-phosphate nonmevalonate pathway in the green alga Scenedesmus obliquus. Biochem. J. 316:73-80. 